\title{
INFORMATION AND COMMUNICATION TECHNOLOGIES IN ENGINEERING EDUCATION
}

\author{
Xavier Maldague ${ }^{1}$, Marina Kuimova ${ }^{2 *}$,Douglas Burleigh $^{3}$, Sofia Skvortsova $^{2}$ \\ ${ }^{1}$ University Laval, 305 Rue de l'Université, Quebec City, Quebec, Canada \\ ${ }^{2}$ National Research Tomsk Polytechnic University, 634050, Tomsk, Russia \\ ${ }^{3}$ La Jolla Cove Consulting, San Diego CA 92117, USA
}

\begin{abstract}
In the emerging digital era it is difficult to train highly-skilled, competent specialists without the use of information and communication technology (ICT). The use of ICT in education increases the motivation to learn, stimulates cognitive activity and independent work, facilitates information exchange, enables interactive communication between teachers and students, and improves learning outcomes. This paper reviews the literature regarding the use of ICTs in education, explores their advantages and challenges, and surveys first-year students at the Institute of Non-Destructive Testing, National Research Tomsk Polytechnic University to determine their attitude toward ICT in foreign language learning.
\end{abstract}

\section{Introduction}

Due to global competition, a university graduate of today must not only possess the specific knowledge and skills needed for his chosen profession, but he must be capable of critical and innovative thinking, and he must be familiar with current software products. Universities strive to use creative and innovative teaching approaches to teach both theoretical and practical knowledge, maximize students' intellectual potential, and train specialists to be able to perform professional tasks and compete in the labour market. In addition to traditional teaching methods and approaches, information and communication technology (ICT) has become a critical tool for engineering training. ICTs include hardware and software, Internet resources, communication technologies, multimedia tools, etc. They expand the learning environment and the range of learning experiences, promote active learning, present the use of the Internet as a critical information resource and offer a wealth of learning online services, courses, and resources.

\section{Discussion and research}

In an era of global communication, expansion of political, economic and cultural activities, higher education is necessary to meet the needs of the society and introduce innovative

\footnotetext{
* Corresponding author: mkuimova@mail.ru
} 
methods and approaches. The inclusion of ICT in higher education creates an open, authentic learning environment, extends educational opportunities, teaches students how to deal with large amounts of information, and provides more autonomy over the learning process.

Computer-based education aims to facilitate the search for educational resources. ICT helps students find educational materials via the Internet and helps teachers create more "learner-centric" instructional activities. In addition, ITCs:

- develop curricula content and provide authentic, relevant information for learning $[1-3]$

- promote an open, flexible teaching/learning environment $[4,5]$;

- motivate learning [6];

- enhance students' cognitive performance [7];

- encourage critical thinking and creativity [8];

- improve academic performance and outcomes [9, 10];

- motivate research activity and stimulate open-ended discovery [11];

- open myriad possibilities for interdisciplinary learning [12];

- further exchange of information and intercultural communication [3, 13, 14].

ICT provides many opportunities to use various Internet technologies to solve many educational and pedagogical problems. ICT offers opportunities to:

- work with databases, electronic encyclopedias and e-learning modules;

- use online materials and interactive Web-based textbooks;

- participate in scientific research, creative projects, video conferences and joint activities in the virtual environment;

- communicate quickly at no cost with other students or speakers of the target language around the world;

- create personal Webpages, blogs, interact through social media and mind maps (publish and distribute learner's multimedia information for an international audience).

The use of information technology improves all kinds of cognitive motives, including interest in knowledge, and the contents and process of learning.

ICT involves students in the learning process, promotes the evaluation of their abilities and an increase in mental activity.

ICT enriches the curriculum, complements students' learning experience and makes teaching and learning more interesting and attractive. ICT is widely used at lectures, practical classes, independent work, various types of assessment (formative and summative), work on projects, research and creative activities. It is used as a tool to help accomplish complex tasks and support students' performance of authentic learning tasks. ICT helps students:

- gather data;

- perform on-line exercises and run simulations;

- work at their own pace;

- develop critical and creative abilities (making and editing videos, creating web pages, writing wikis, making presentations, etc.);

- monitor learning process and perform self-assessment tasks;

- take responsibility for their learning and become independent, self-directed learners prepared for lifelong on-going learning.

ICT permits access to online course materials or virtual classrooms and enables blended and distance learning [15]. Even with all it's benefits, ICT is not a substitute for a teacher. Traditional teaching methods and approaches must still be used in conjunction with ICT. 
Teachers serve as facilitators; they must be aware of a wide variety of available materials so they can recommend multimedia and other resources effectively, and know how to best deploy them to meet the needs of students [16-20].

The implementation of ITC in foreign language classes provides access to materials and information in the language (one-way communication) and communication with the teacher and other students and native speakers (two-way communication). In addition, it helps:

- promote motivation to foreign language learning;

- provide access to current, up-to-date materials from the country or countries where the target language is spoken;

- offer individual learning pathways and adapt the teaching material to learners' needs;

- provide a means to focus on a specific aspect of language (pronunciation, grammar, vocabulary, etc.);

- provide additional possibilities for independent work aimed at the development of language skills;

- provide a fast feedback to students' answers;

- translate words and phrases from one language into another (electronic translators and dictionaries);

- increase cultural awareness (the Internet affords the means to find out more about history, culture and traditions of countries throughout the world);

- train for professional cross-cultural communication;

- provide access to on-line courses, materials and tests [21, 22].

The use of ICT in teaching is not problem-free. There are challenges and barriers preventing teachers from using ICT:

- inability of universities to provide the physical space for the use of electronic resources;

- poor quality ICT equipment;

- poor quality (slow or intermittent) Internet access;

- teachers may have insufficient computer skills or may lack the ability to use the available technology adequately;

- time-consuming preparation of digital materials and a shortage of class time;

- reduction in personal contact with students;

- students' inability to study independently [23].

Thus, the successful integration of ICT in language learning results in:

- a flexible approach to learning using both computer-based and traditional teaching methods in the classroom;

- the teacher's continuous adjustment to the varying demands of professional competence and knowledge;

- careful and critical selection of Internet resources;

- adaptation to the changing expectations of students;

- teacher's encouragement and support of students.

In our paper we surveyed 43 first-year students of the Institute of Non-Destructive Testing, National Research Tomsk Polytechnic University to determine their attitude towards the integration of ICT in foreign language teaching. The students were given the following questionnaire and asked to provide their views (Table 1). 
Table 1. Questionnaire on students' attitude towards ICT in foreign language learning.

\begin{tabular}{|c|l|c|c|c|}
\hline № & \multicolumn{1}{|c|}{ Question } & Agree (\%) & $\begin{array}{c}\text { Disagree } \\
(\%)\end{array}$ & $\begin{array}{c}\text { Don’t know } \\
(\%)\end{array}$ \\
\hline 1 & $\begin{array}{l}\text { I am comfortable using technology } \\
\text { in foreign language classes }\end{array}$ & 74.4 & 18.6 & 7 \\
\hline 2 & $\begin{array}{l}\text { I think that getting information from } \\
\text { ICT is better than using printed } \\
\text { materials/textbooks }\end{array}$ & 18.6 & 60.5 & 20.9 \\
\hline 3 & $\begin{array}{l}\text { I think that ICT allows me to learn } \\
\text { more in the time I have for studies }\end{array}$ & 39.5 & 25.6 & 34.9 \\
\hline 4 & $\begin{array}{l}\text { I think that ICT improves my } \\
\text { learning }\end{array}$ & 76.8 & 20.9 & 2.3 \\
\hline 5 & $\begin{array}{l}\text { I think that the use of ICT allows me } \\
\text { to take greater control of my } \\
\text { language learning }\end{array}$ & 65.1 & 20.9 & 14 \\
\hline 6 & $\begin{array}{l}\text { I use ICT to create my own digital } \\
\text { learning resources (Web-pages, } \\
\text { blogs, mind maps, etc.) }\end{array}$ & 18.6 & 51.2 & 30.2 \\
\hline 7 & $\begin{array}{l}\text { I use ICT to communicate with } \\
\text { international peers on topics of } \\
\text { personal interest }\end{array}$ & 53.5 & 41.9 & 4.6 \\
\hline 8 & $\begin{array}{l}\text { I use ICT to communicate with } \\
\text { international peers on education } \\
\text { related matters }\end{array}$ & 39.5 & 55.8 & 4.7 \\
\hline 9 & $\begin{array}{l}\text { ICT (e.g. the Internet) permits access } \\
\text { to current learning materials }\end{array}$ & 79.1 & 11.6 & 9.3 \\
\hline 10 & $\begin{array}{l}\text { I would like to use ICT more in } \\
\text { language learning }\end{array}$ & 37.2 & 46.5 & 16.3 \\
\hline
\end{tabular}

Thus, the survey shows that the students have a positive attitude towards the use of ICT as a tool to enhance language learning. However, they prefer to get information from printed materials rather than from ICT. In addition, students indicated that they find webinars $(9.3 \%)$ and on-line courses (14\%) less interesting and productive than traditional lessons $(76.7 \%)$ due to the lack of face-to-face contact with their teachers. In fact, such findings are confirmed even in engineering classes where student attention «gets reduced» rapidly if teachers rely too heavily on ICT. So far, a balanced mixed of active teacher presence and ICT was found the best and only «teacher's own experience» combined to her/his «feeling of the class» has been the key of successful ICT implementations [24].

The survey shows that students prefer to communicate with international peers on personal interests rather than on educational issues. The students don't wish to use more ICT in foreign language lessons and this indicates that TPU teachers make an effective, balanced use of ICT to create educational experiences which enrich and extend students' academic abilities and needs

\section{Conclusion}

Today the ability to independently find, analyze, evaluate, interpret and synthesize information is very important in the educational process. ICT helps to increase the quality 
of education and has become an indispensable part of the contemporary learning environment.

The integration of ICT into the educational process has great potential for both teachers and students. It helps teachers improve and develop their teaching methods. ICT diversifies students' activities, improves their attention and cognitive motives, increases creative potential and knowledge, expands self-education and self-development, and increases selfregulated learning and independent work. ICT helps bring foreign language and culture to life and make it more tangible. It is worth noting that ICT alone cannot provide a comprehensive basis for language learning. It should be accompanied by teacher's guidelines, traditional teaching methods, conventional textbooks, workbooks, and audio and video materials.

\section{References}

[1] B. Shu'aibu, M. Usman, M.S. Saud, Y. Kamin, KJSS 36, 591 (2015)

[2] D.C.-T. Lo, K. Qian, W. Chen, Proc. FIE, 7344089 (2015) doi: 10.1109/FIE.2015.7344089

[3] P. Resta, T. Laferrière, Educ Inform Tech. 20, 743 (2015) doi: 10.1007/s10639015-9419-Z

[4] A. Lillo-Bañuls, J.F. Perles-Ribes, R. Fuentes, JTTT 16, 81 (2016) doi: 10.1080/15313220.2015.1118367

[5] M.V. Kuimova, O.D. Zvekov, iJET 11, 4 (2016) doi: 10.3991/ijet.v11i04.5430

[6] N. Aghaee, C. Keller, Comput Educ. 94, 276 (2016) doi: 10.1016/j.compedu.2015.11.006

[7] A. Chaldogeridis, Proceedings of 2015 International Conference on Interactive Mobile Communication Technologies and Learning, IMCL 2015, 7359635 (2015) doi: 10.1109/IMCTL.2015.7359635

[8] G. McMahon, Educ Technol Soc. 12, 269 (2009)

[9] G.A. Kruchinina, L.I. Tararina, E.E. Sokolova, E.V. Limarova, I.V. Muskhanova, S.M. Arsaliyev, F.U. Bazayeva, N.P. Tagirova, IRMM 6, 104 (2016)

[10] C.P. Van der Westhuizen, C. Nel, B.W. Richter, Educ Technol Soc. 15, 190 (2012)

[11] D.K. Saini, L.S. Prakash, H. Gaur, Advances in Intelligent Systems and Computing 409, 335 (2016) doi: 10.1007/978-981-10-0135-2_33

[12] D. Ktoridou, E. Doukanari, IMCL, 7 (2015) doi: 10.1109/IMCTL.2015.7359605

[13] S. Ribeiro, Lang Intercult Comm 16, $69 \quad$ (2016) doi: 10.1080/14708477.2015.1113752

[14] Y. Jiugen, X. Ruonan, C. Li, Proceedings - 2015 7th International Conference on Information Technology in Medicine and Education, ITME 2015, 647 (2015) doi: 10.1109/ITME.2015.85

[15] Y. Pan, MATEC Web of Conferences 44, 01075 (2016) doi: $10.1051 /$ matecconf $/ 20164401075$

[16] M. Kuimova, D. Burleigh, A. Trofimova, MATEC Web of Conferences 48, 06006 (2016) doi: 10.1051/matecconf/20164806006

[17] A. Uvarov, I. Lezhnina, K. Overchuk, A. Starchak, Proceedings of 2014 International Conference on Mechanical Engineering, Automation and Control Systems, MEACS 2014, 6986935 (2014) doi: 10.1109/MEACS.2014.6986935

[18] N.M. Natalinova, O.V. Galtseva, E.A. Moldovanova, 2016 Third International Conference on Electrical, Electronics, Computer Engineering and their Applications (EECEA), 52 (2016) doi: 10.1109/EECEA.2016.7470765 
[19] A.Y. Petrova, O.N. Chaikovskaya, I.V. Plotnikova, Technical Physics 60, 592 (2015) doi: 10.1134/S1063784215040222

[20] M. Kuimova, A. Kiyanitsyna, A. Truntyagin, SHS Web of Conferences 28, 01129 (2016) doi:10.1051/shsconf/20162801129

[21] E. Dm. Griaznova, PSR 16, 4 (2014)

[22] D. Pusca, D.O. Northwood, WTE\&TE 14, 77 (2016)

[23] H. Salehi, Z. Salehi, IJEEEE 2, 4 (2012)

[24] X. Maldague, ECE dept., U. Laval, private communication (2016) 